\title{
Identification of the Active Principle Conferring Anti-Inflammatory and Antinociceptive Properties in Bamboo Plant
}

\author{
Bruna Araujo Sousa ${ }^{1}$, Osmar Nascimento Silva ${ }^{2,3}{ }^{(D)}$, William Farias Porto ${ }^{1,4} \mathbb{D}$, Thales Lima Rocha ${ }^{5}$, \\ Luciano Paulino Silva 5 (D), Ana Paula Ferreira Leal ${ }^{2}$, Danieli Fernanda Buccini ${ }^{2}$, \\ James Oluwagbamigbe Fajemiroye ${ }^{3,6}$, Ruy de Araujo Caldas ${ }^{2}$, Octávio Luiz Franco ${ }^{1,2,7}$ (D), \\ Maria Fátima Grossi-de-Sá ${ }^{1,5}$, Cesar de la Fuente Nunez ${ }^{8,9,10}$ and Susana Elisa Moreno ${ }^{2, *}$
}

check for updates

Citation: Araujo Sousa, B.;

Nascimento Silva, O.; Farias Porto, W.; Lima Rocha, T.; Paulino Silva, L.; Ferreira Leal, A.P.; Buccini, D.F.; Oluwagbamigbe Fajemiroye, J.; de Araujo Caldas, R.; Franco, O.L.; et al. Identification of the Active Principle Conferring Anti-Inflammatory and Antinociceptive Properties in Bamboo Plant. Molecules 2021, 26, 3054. https://doi.org/10.3390/ molecules26103054

Academic Editor: Silvie Rimpelová

Received: 8 March 2021

Accepted: 31 March 2021

Published: 20 May 2021

Publisher's Note: MDPI stays neutral with regard to jurisdictional claims in published maps and institutional affiliations.

Copyright: (c) 2021 by the authors. Licensee MDPI, Basel, Switzerland. This article is an open access article distributed under the terms and conditions of the Creative Commons Attribution (CC BY) license (https:// creativecommons.org/licenses/by/ $4.0 /)$.
1 Programa de Pós-Graduação em Ciências Genômicas e Biotecnologia, Universidade Católica de Brasília, Brasília CEP 70790-160, DF, Brazil; soubrunabio@gmail.com (B.A.S.); williamfp7@yahoo.com.br (W.F.P.); ocfranco@gmail.com (O.L.F.); fatimasa@cenargen.embrapa.br (M.F.G.-d.-S.)

2 S-Inova Biotech, Programa de Pós-Graduação em Biotecnologia, Universidade Católica Dom Bosco, Campo Grande CEP 79117-900, MS, Brazil; osmar.silva@catolica.edu.br (O.N.S.); analeal.biotec@gmail.com (A.P.F.L.); dfbuccini@gmail.com (D.F.B.); caldasruy@gmail.com (R.d.A.C.)

3 Centro Universitário de Anápolis, Unievangélica, Anápolis CEP 75083-515, GO, Brazil; jfajemiroye@gmail.com

4 Porto Reports, Brasília CEP 72236-011, DF, Brazil

5 Embrapa Recursos Genéticos e Biotecnologia (Cenargen), Brasília CEP 70770-917, DF, Brazil; thales.rocha@embrapa.br (T.L.R.); lucianopaulinosilva@gmail.com (L.P.S.)

6 Núcleo de Estudos e Pesquisas Tóxico-Farmacológicas, Universidade Federal de Goiás, Goiânia 74605-220, GO, Brazil

7 Departamento de Patologia Molecular, Faculdade de Medicina, Universidade de Brasília, Brasília CEP 70910-900, DF, Brazil

8 Research Laboratory of Electronics, Massachusetts Institute of Technology, Cambridge, MA 02139, USA; cfuente@mit.edu

9 Department of Biological Engineering, The Center for Microbiome Informatics and Therapeutics, Massachusetts Institute of Technology, Cambridge, MA 02139, USA

10 Department of Electrical Engineering and Computer Science, The Center for Microbiome Informatics and Therapeutics, Massachusetts Institute of Technology, Cambridge, MA 02139, USA

* Correspondence: smoreno@ucdb.br; Tel.: +55-(67)-3312-3465

Abstract: Early plants began colonizing earth about 450 million years ago. During the process of coevolution, their metabolic cellular pathways produced a myriad of natural chemicals, many of which remain uncharacterized biologically. Popular preparations containing some of these molecules have been used medicinally for thousands of years. In Brazilian folk medicine, plant extracts from the bamboo plant Guadua paniculata Munro have been used for the treatment of infections and pain. However, the chemical basis of these therapeutic effects has not yet been identified. Here, we performed protein biochemistry and downstream pharmacological assays to determine the mechanisms underlying the anti-inflammatory and antinociceptive effects of an aqueous extract of the G. paniculata rhizome, which we termed AqGP. The anti-inflammatory and antinociceptive effects of $A q G P$ were assessed in mice. We identified and purified a protein (AgGP), with an amino acid sequence similar to that of thaumatins $(\sim 20 \mathrm{kDa})$, capable of repressing inflammation through downregulation of neutrophil recruitment and of decreasing hyperalgesia in mice. In conclusion, we have identified the molecule and the molecular mechanism responsible for the anti-inflammatory and antinociceptive properties of a plant commonly used in Brazilian folk medicine.

Keywords: medicinal plants; natural products; folk medicine; neutrophil migration; pain and thaumatin 


\section{Introduction}

Inflammation is a mechanism of host-defense that mounts local or generalized responses to confer protection against harmful stimuli such as injury or invasion by microbial pathogens. One such response is pain, which alerts the body that an injury has occurred [1] However, this defense mechanism can itself become harmful to the host, causing severe tissue damage and potentially pain, resulting from chronic inflammation [2]. In addition to the host-protective role of neutrophils through phagocytosis and antimicrobial activity, these cells may exhibit deleterious functions [3,4]. Neutrophils can migrate to tissues and release lytic factors, reactive oxygen species, and other pro-inflammatory mediators, contributing to organ damage and chronic inflammation [5]. Chronic inflammation is a consequence of an exacerbated inflammatory response and is typically treated with anti-inflammatory drugs [6]. The most widely prescribed anti-inflammatory drugs are the nonsteroidal anti-inflammatory drugs (NSAIDs), of which non-selective NSAIDs are the oldest and most frequently prescribed worldwide [7]. The most common side effects of these drugs include gastrointestinal erosions and renal and hepatic failure [7,8]. Therefore, it is necessary to discover novel drugs against chronic inflammation that have fewer adverse effects [9].

Ethnopharmacological reports have demonstrated the use of plant extracts for the treatment of inflammatory disease and pain $[10,11]$. Indeed, many of these compounds produced by plants have been used in folk medicine for thousands of years. Early plants began colonizing earth about 450 million years ago and have exploited their versatile metabolism to produce numerous natural products that may serve as medicines [12]. One commonly used strategy to identify new drugs involves exploring the chemistry of folk medicinal plant extracts [13]. Among these natural products, peptides and proteins have been described that interact with animal systems, including the uterotonic cyclotides [14], immunomodulatory peptides [15-19], and anti-inflammatory thaumatin proteins [20,21].

Medicinal chemistry campaigns performed on plant extracts enabled the discovery of new anti-inflammatory compounds that are currently used in medicine [22-24]. In natural product discovery, medicinal chemistry is also key to ensure that any novel agent derived from extracts displays the appropriate safety and efficacy profiles $[25,26]$. Safety validation programs also stimulate the utilization of these plant extracts in public health assistance programs. In Brazil, the "Living Pharmacies Project" [27] has carried out ethnobotanical studies of more than 500 species, based on both folk knowledge and bibliographical research. These plants were cultivated in small units, or "Living Pharmacies", each consisting of a medicinal vegetable garden and a workshop with the capacity to serve, free of charge, a community of 2000 to 3000 families [27]. Among the plants used in the project, ten species were found to provide therapeutic effects for $80 \%$ of the most common diseases in the area, including cutaneous and mucosal infections, digestive and respiratory diseases, rheumatic pain, and intestinal parasitic infections [27].

Here, we investigated the plant species Guadua paniculata Munro paniculata (Poaceae, subfamily Bambusoideae) as a potential source of novel anti-inflammatory agents. Isolated from the Brazilian Cerrado and used as part of the Living Pharmacies Project, this species has long been used in folk Brazilian medicine for the treatment of pain, thus pointing towards a potential anti-inflammatory effect. Several species from the Bambusoideae subfamily have been reported to have therapeutic properties for the treatment of hypertension, obesity, paralysis, sweating, and inflammation [28-30]. The present study evaluated aqueous extracts from the G. paniculata rhizome $(A q G P)$ for anti-inflammatory activity and toxicity towards human cells and identified the compound responsible for its pharmacological action.

\section{Results and Discussion}

Validation of the safety of plant extracts is an essential part of evaluating the effectiveness of their pharmacological properties. To evaluate $A q G P$ toxicity, two in vitro methodologies were used: hemolytic activity towards caprine cells and effects on cell 
viability using murine and human cells. Cell viability was evaluated at six concentrations of $\operatorname{AqGP}(0.32,0.64,1.28,2.56,5.12$, and $10.24 \mathrm{mg} / \mu \mathrm{L})$. The results showed a very low percentage of hemolysis $(0.66 \%)$ at all the tested concentrations (Figure 1A). In MTT assays, when murine fibroblasts $(\mathrm{NIH} / 3 \mathrm{~T} 3$ cell lines) were exposed to these concentrations of AqGP $(0.32,0.64,1.28,2.56,5.12$, and $10.24 \mathrm{mg} / \mu \mathrm{L})$, the viability of the cell line NIH/3T3 was reduced by $26 \%$ and $30 \%$, when cells were exposed to the higher doses tested (5.12 and $10.24 \mathrm{mg} / \mathrm{mL}$, respectively) (Figure 1B). The same procedure was performed using human breast cancer MCF-7 cells, for which no reduction in viability was observed even at the highest $A q G P$ concentrations tested $(10.24 \mathrm{mg} / \mathrm{mL}$ ) (data not shown). Given the absence of cytotoxic effects towards mammalian cells, extensive in vivo experiments were performed. The harmful concentration of $A q G P$ observed was approximately four times higher than the active one, demonstrating a comfortable safety margin between the active and harmful doses of the molecules. Despite the possible allergenic epitope in thaumatin, these results indicate that using the extract in question is safe in practice [31,32].
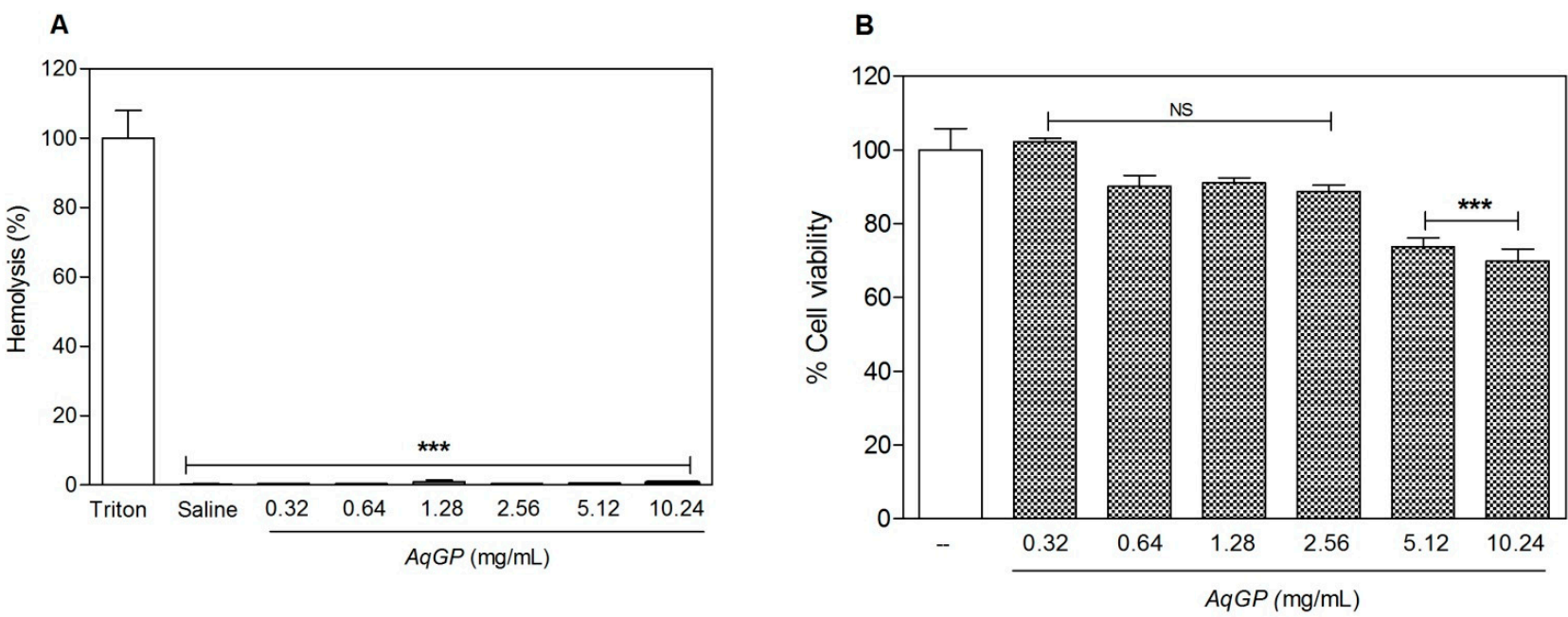

Figure 1. Effects of $A q G P$ in vitro against goat erythrocytes and murine cell line NIH/3T3. (A) The hemolytic activity of AqGP on goat erythrocytes was evaluated. (B) The effect of AqGP on cell viability of the cell line NIH/3T3 was evaluated by MTT assay. ${ }^{* * *} p<0.05$ difference as compared to the untreated group, which received only water (ANOVA followed by Bonferroni's test); NS: not significant.

Evaluation of the anti-nociceptive response was performed using formalin and contortion tests [33]. Compounds that act on the first phase (phase 1) are characteristic of drugs with central analgesic activity. On the other hand, compounds that act on the later phase (phase 2) are characterized by the development of a local inflammatory process, indicating a peripheral analgesic activity generated by mediators released during inflammation that sensitize nociceptors [34]. In phase 1, the subcutaneous administration of $A q G P$ at a concentration of $1.0 \mathrm{mg} / \mathrm{kg}$ of the extract showed significant inhibition (48\%) of nociception, when compared with the treatment with formalin in phase 1 (after 0 to $5 \mathrm{~min}$ of the nociceptive stimulation; Figure 2A). In phase 2 (after 15 and $30 \mathrm{~min}$ of the nociceptive stimulation), at doses of $1.0,5.0$, and $10 \mathrm{mg} / \mathrm{kg}$, mice exhibited a significant reduction $(2.5 \%)$ in the frequency of paw-licking after injection of $20 \mu \mathrm{L}$ of formalin (Figure 2A). Inhibition of nociception ranged from 43 to $67 \%$ for treated animals compared with animals that received only the noxious stimulus. By comparison, treatment with acetylsalicylic acid (ASA) (i.e., a drug with proved analgesic activity) at a dose of $100 \mathrm{mg} / \mathrm{kg}$ inhibited nociception by only $30 \%$ at the same stage. In order to confirm the peripherical analgesic effect of $A q G P$, the mouse writhing test was performed (Figure 2B). Similar to results observed in the formalin test, subcutaneous administration of $A q G P$ at a concentration of $1.0 \mathrm{mg} / \mathrm{kg}$ of the extract showed a reduction $(25 \%)$ of nociception when compared with the control treatment with acetic acid. At the concentrations of 5.0 and $10 \mathrm{mg} / \mathrm{kg}, A q G P$ as was able to inhibit the 
frequency of contortions (50\%) for treated animals compared with mice that received only the noxious stimulus (Figure 2B). This result was similar to that observed in mice treated with acetylsalicylic acid.

\section{A}

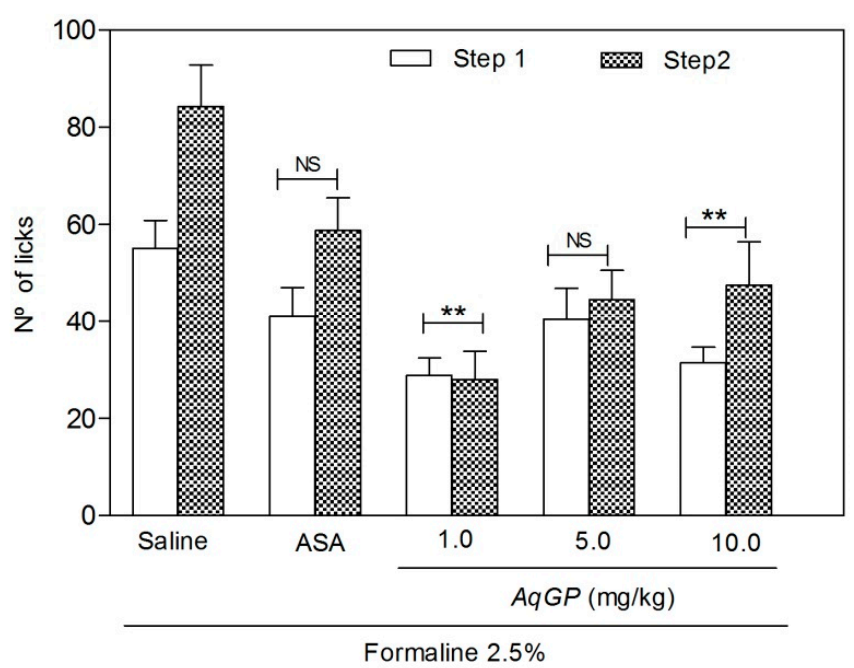

B

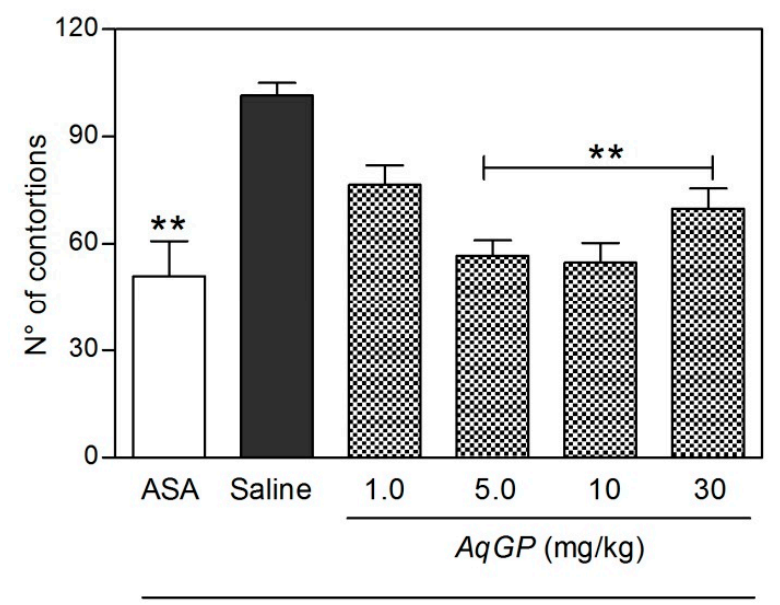

Acetic acid $(0.8 \%)$

Figure 2. Effect of $A q G P$ pre-treatment on hyperalgesia in mice. All animals were pre-treated with the $A q G P$ extract at concentrations of 1,5 , or $10 \mathrm{mg} / \mathrm{kg}$ or acetylsalicylic acid $(100 \mathrm{mg} / \mathrm{kg}) 15 \mathrm{~min}$ after the injection of nociceptive stimulant. (A) Hyperalgesia was induced by formalin $(20 \mu \mathrm{L}, 2.5 \%)$ in the sub-plantar region of the right paw. The number of licks was counted in two phases, phase 1 from 0 to $5 \mathrm{~min}$, and phase 2 from 15 to $30 \mathrm{~min}$. (B) Hyperalgesia induced by acetic acid $(0.8 \%, 100 \mu \mathrm{L}$, i.p). The frequency of abdominal contortions was counted for $30 \mathrm{~min}$. The results are expressed as the mean \pm SEM of 5 animals. ${ }^{* *} p<0.05$ when compared to the untreated control group (ANOVA followed by Bonferroni test). NS: not significant.

The anti-inflammatory properties of $A q G P$ were analyzed by testing neutrophil migration to the peritoneal cavity of mice with peritonitis induced by injection of $4 \%$ thioglycolate. The use of irritants such as thioglycolate characteristically leads to the influx of neutrophils to the injured tissue, one of the key features of the inflammatory process [35]. Thus, thioglycolate has been extensively used as an efficient method to induce inflammation [36]. As observed in Figure 3A, the subcutaneous administration of AqGP at doses of 1.0, 5.0, 10 , and $30 \mathrm{mg} / \mathrm{kg}$ administered subcutaneously in mice significantly reduced neutrophil migration to the intraperitoneal cavity (where inflammation had been induced by $4 \%$ thioglycolate, see methods). When treatment using thioglycolate (positive control) was compared to the negative control, the inhibitory activity of AqGP ranged from 53 to $88 \%$. The extract modestly decreased neutrophil migration at $1.0 \mathrm{mg} / \mathrm{kg}^{-1}$ and exhibited its highest inhibitory potential at $5.0 \mathrm{mg} / \mathrm{kg}$. The concentrations used in this assay showed no significant differences between their inhibition levels, indicating that increasing the concentration of $A q G P$ does not enhance its inhibition potential. Although the tests performed in this study did not clearly delineate the mechanism of action of $A q G P$, it is plausible that the concentrations used lie within a range of saturation in which the active compound concentration does not lead to a progressive increase in activity (Figure 3). 


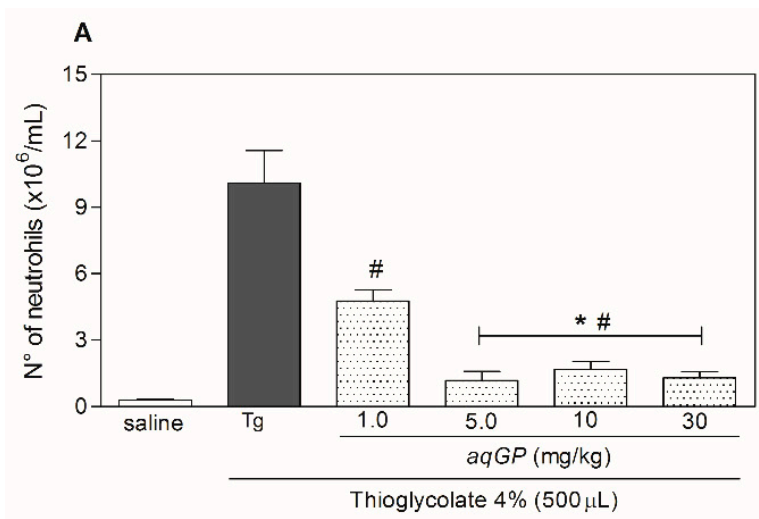

B

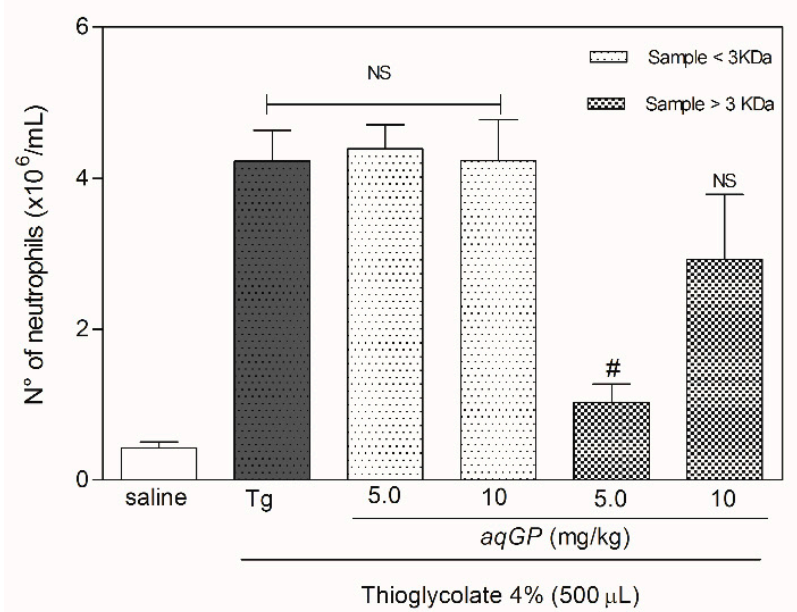

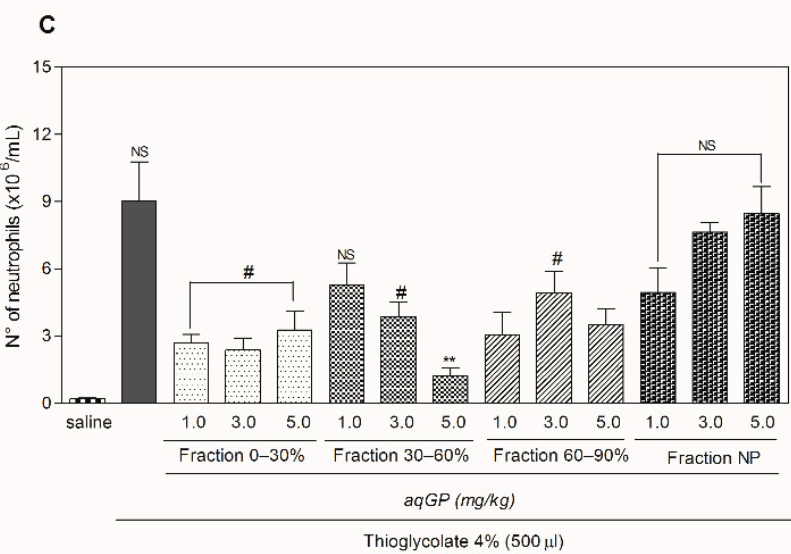

D

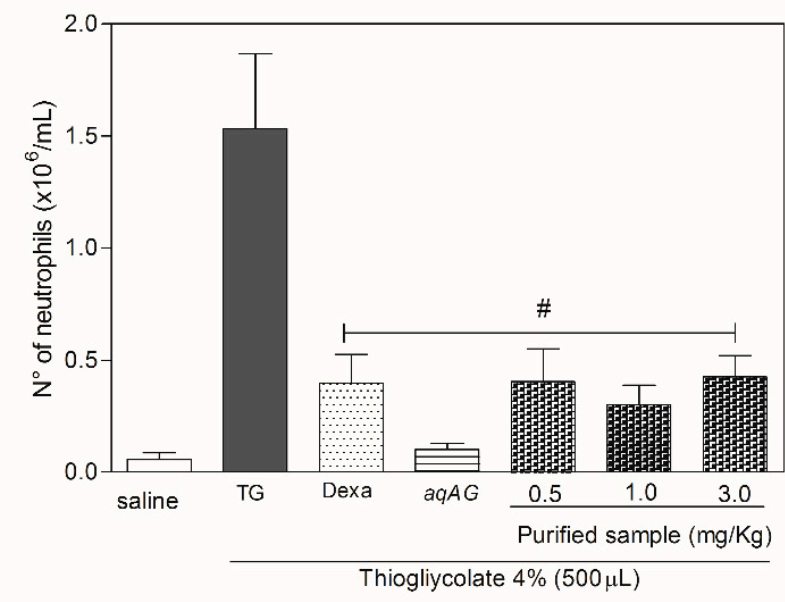

Figure 3. Anti-inflammatory bioassay-guided fractionation of $A q G P$. (A) Neutrophil migration to the peritoneal cavity in mice pre-treated with $A q G P$. (B) The migration of neutrophils to the peritoneal cavity was evaluated for mice pre-treated with fractions of $A q G P$ collected from the ammonium sulfate precipitation process. (C) The migration of neutrophils to the peritoneal cavity in mice pre-treated with the peak three fraction (retention $29.9 \mathrm{~min}$ ) obtained from fractionation by reverse phase chromatography of the $0-30 \%$ saturation fraction by ammonium sulfate of AqGP. (D) Anti-inflammatory activity after rechromatography in a hydrophobic affinity column of C4. Each experimental group had $n=5$. Results are expressed as mean \pm SEM of the number of neutrophils per mL. \# $p<0.05$ difference as compared to the untreated group injected with thioglycolate; ${ }^{*} p<0.05$ difference as compared to the group treated with $a q G P 1.0 \mathrm{mg} / \mathrm{kg}$; ${ }^{* *} p<0.05$ difference as compared to the group treated with aqGP fraction 0-30\% (ANOVA followed by Bonferroni's test); NS: not significant.

The AqGP in the second phase demonstrated a peripheral analgesic effect, by which it would act on the inflammatory mediators that lead to pain. Consistent with these data, the acetic acid-induced abdominal contortions assay, a model of visceral pain [37], showed that all doses of $A q G P$ were able to inhibit the nociceptive response in mice. Those data corroborate the anti-inflammatory activity demonstrated by the neutrophil migration test and are in agreement with the hypothesis that the use of AqGP in folk medicine is due to its activity to reduce inflammatory pain. In fact, separately analyzing the action of AqGP at a concentration of $1 \mathrm{mg} / \mathrm{kg}$ in both phases of the test, we observed a different behavior from other concentrations. The concentration of $1 \mathrm{mg} / \mathrm{kg}$ showed similar compounds that act on the central nervous system and are active in both phases. However, other tests that allow the evaluation of compounds on the central nervous system, such as the hot-plate test, should be conducted to further clarify this activity. The drug ASA used as a reference in the assay behaved as expected in this study, only acting on the second stage as it exerted a peripheral analgesic action [38]. 
Therefore, in order to evaluate and identify the main components responsible for the pharmacological activity of $A q G P$, the extract was purified and at each purification step, biological assays were performed. For each fractionation step, the most active fractions were selected for further purification steps (Figure 3). After dialysis, the internal dialysate containing molecules larger than $3.5 \mathrm{kDa}$ exhibited an anti-inflammatory activity, inhibiting neutrophil migration by $75 \%$ when compared to the negative control, at a concentration of $5 \mathrm{mg} / \mathrm{kg}$ (Figure 3C). The external dialysate, however, was not active. The active internal dialysate sample was then precipitated by saturation at $0-30 \%, 30-60 \%$, and $60-90 \%$ with ammonium sulfate. At all tested doses $(1,3$, and $5 \mathrm{mg} / \mathrm{kg}$ ), the fraction $0-30 \%$ presented activity and the percentage of inhibition varied between 60 and 71\% (Figure 3B). The fraction with a saturation of 30-60\% demonstrated activity only at concentrations of 3 and $5 \mathrm{mg} / \mathrm{kg}$, with a percentage inhibition of $53 \%$ and $85 \%$, (Figure 3B). The fraction with saturation of $60-90 \%$ showed a percentage of inhibition of $53-85 \%$ for neutrophils in comparison with the non-treated group and that injected with thioglycolate (Figure 3B).

The purification process proceeded with the fraction $0-30 \%$ saturation, which had exhibited the highest anti-inflammatory activity. This fraction was subjected to hydrophobic affinity chromatography using a $\mathrm{C}_{4}$ semi-preparative column, resulting in the separation of four distinct peaks: Peak 1: retention time (RT) $5.39 \mathrm{~min}, 5 \%$ TCA + 0.1\% TFA; Peak 2: RT 21.75 min 38\% TCA + 0.1\% TFA; Peak 3: RT 29.9 min 46\% TCA + 0.1\% TFA; and Peak 4: RT 36.9 min and $52 \%$ TCA + 0.1\% TFA, respectively. Only fraction three showed activity, with the percentage of inhibition ranging from 76 to $88 \%$. A bioassay using this material at doses of $0.5,1.0$, and $3.0 \mathrm{mg} / \mathrm{kg}$ demonstrated a noteworthy inhibition from 72 to $80 \%$ of neutrophil migration into the peritoneal cavity of the mice. The total AqGP and reference drug dexamethasone, also evaluated in the assay, had inhibitory activities of $93 \%$ and $74 \%$, respectively (Figure 3D).

The $A q G P$ and all its fractions previously selected by the neutrophil testing migration were submitted to denaturing electrophoresis. The proteins were separated in a sodium dodecyl sulfate polyacrylamide gel $(12 \%)$ and were found to have molecular masses ranging from 20 to $50 \mathrm{kDa}$ (Figure 4). A single band with a molecular mass around $20 \mathrm{kDa}$ was observed for the single fraction purified by affinity chromatography using an analytical $\mathrm{C}_{4}$ column (Figure 4).

The protein purified using analytical $\mathrm{C}_{4}$ affinity chromatography and exhibiting antiinflammatory properties was subjected to mass spectrometry analysis-MALDI-TOF, for a more detailed evaluation (Figure 4). The spectrum generated by analysis in reflector mode with mass-to-charge ratio $(\mathrm{m} / \mathrm{z})$ from 1000 to 3500 did not show any ionization product. However, the spectrum generated by analysis in a linear mode (with $m / z$ ranging from 4000 to 24,000 ) exhibited three ions at different $m / z$, which seemed to correlate with the same macromolecule in different degrees of protonation. The largest ion was with $m / z 22,400$, and within this correlation the monocharged shape corresponded to $[\mathrm{M}+\mathrm{H}]^{+}$; then formed a doubly-charged ion $[\mathrm{M}+2 \mathrm{H}]^{+}$at $m / z$ of 11,200 , and triply-charged form $[\mathrm{M}+3 \mathrm{H}]^{+}$at $m / z$ of about 7400. The fraction was then subjected to MALDI in-source decay (ISD) using the matrix 1,5-diaminonaphthalene (DAN), and spectra were acquired with the target ion at $m / z 22,400$. The pattern of fragmentation obtained and the distances between each of the ions allowed us to obtain a de novo sequence of 28 amino acid residues (LDPGQSWDLNVAAGTPAARIWPRTGCTF). Isobaric residues (I/L and K/Q) were indicated after comparison with sequences from other organisms available in databases. This same sample was also subjected to analysis in the linear mode for larger $m / z$ ranging from 20,000 to 140,000. The results again showed the presence of an ion at 22,400 and the presence of dimers, trimers, and other multimeric degrees. However, the molecule in its native form may not present this type of organization, which was possibly generated by the technique. 


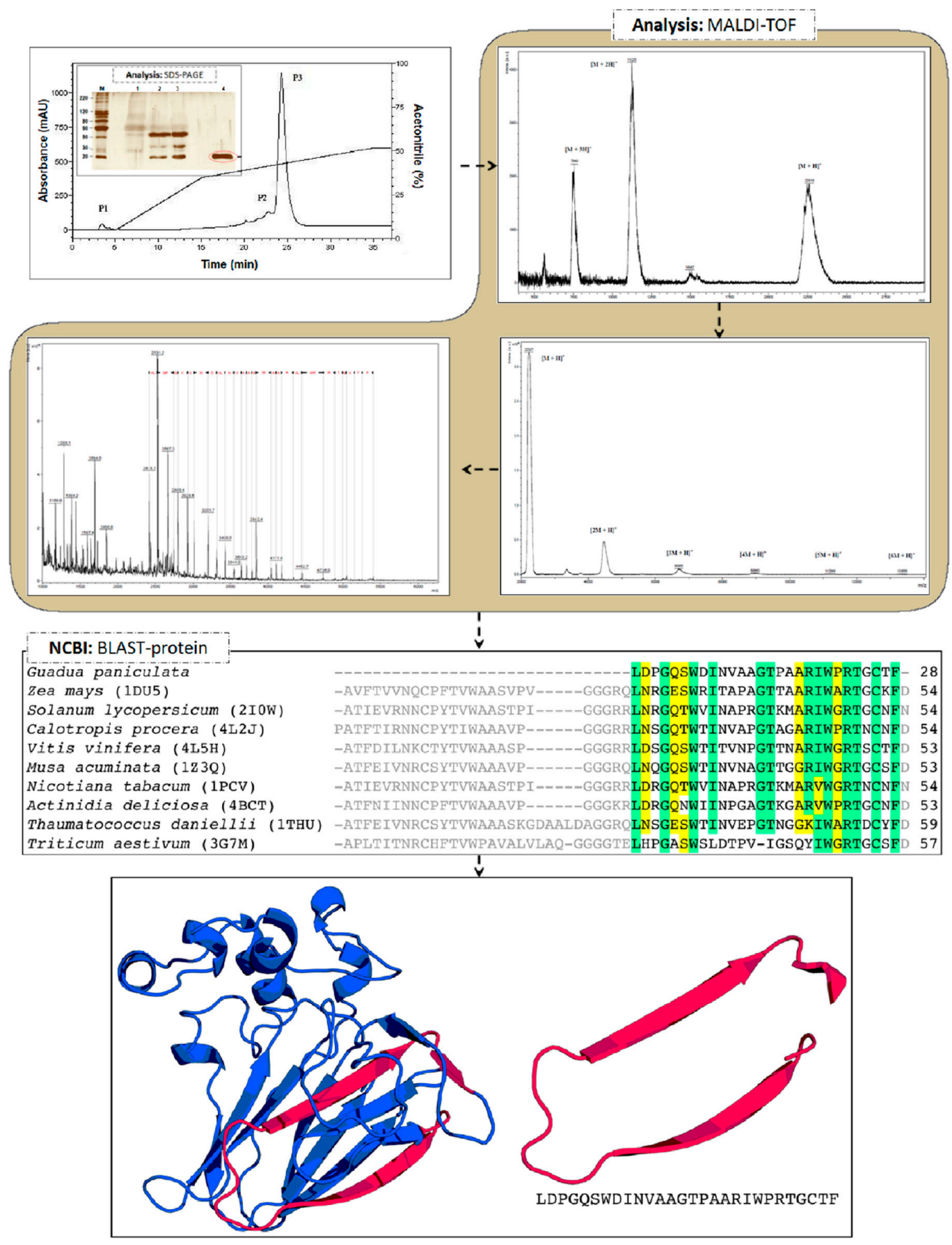

Figure 4. Steps for molecular identification of the bioactive compound isolated from $A q G P$, and classification as a thaumatinlike protein. Molecular mass profiles resulting from the first three fractionation steps. Where: M: molecular weight marker; 1: AqGP; 2 : fraction 0-30\%, precipitation with ammonium sulfate; 3: fraction 0-30\%, precipitation with ammonium sulfate, dialyzed; 4: fraction with retention time of $29.9 \mathrm{~min}$, obtained by HPLC C4 semipreparative column. The sequence alignment of the fragment retrieved from mass spectrometry with the PDB (Protein Data Bank) hits (the respective codes are between brackets) is: Zea mays [39], Solanum lycopersicum [40], Calotropis procera [41], Vitis vinifera [42], Musa acuminate [43], Nicotina tabacum [44], Actinidia deliciosa (Pavkov-Keller et al., unpublished), Thaumatococcus daniellii [45], and Triticum aestivum [46]. Positions with conserved residues (80\%) are highlighted in green; positions with similar residues (80\%) are highlighted in yellow. The predicted three-dimensional structure of the chimeric zeamatin harboring the fragment of AqGP. The fragment is highlighted in pink. The structure shows virtually no modification, compared to zeamatin (RMSD = $0.2 \AA$ ). The model shows a discrete optimized protein energy (DOPE) score of 0.3 ; in the Ramachandran plot, $87.4 \%$ and $12 \%$ of residues are in favored and allowed regions, respectively; with a Z-score on ProSA of -5.91 . 
The 28 amino acid residues sequenced were then submitted to a local alignment against the NCBI protein database using BLASTp. The alignment results showed a high similarity of our sequence with a conserved region from thaumatin-like proteins, related to plant defense mechanisms against pathogens (Figure 4). The mature proteins from this family have $\sim 200$ amino acid residues, which is in agreement with the molecular mass observed in SDS-PAGE (Figure 4) and was confirmed by MALDI-TOF mass spectrometry. Comparing the sequence with the database showed a $57 \%$ similarity with the protein osmotin, which has been described in mouse studies as an anti-inflammatory agent for colitis [21], in addition to presenting a neuroprotective effect in excitotoxic diseases [47]. Osmotin has a high similarity in structure with adiponectin protein, which is well described in the literature due to its anti-inflammatory action [20].

The three-dimensional structure of thaumatins has three domains: domain I consists of a $\beta$-sheet; domain II, an extended $\alpha$-helix associated with three shorter $\alpha$-helices; and domain III, a $\beta$-hairpin turn with an extended loop (Figure 4). However, one thaumatin subfamily has been described that lacks domain II; the members of this subfamily are characterized as small thaumatin-like proteins [46]. In order to verify whether the identified thaumatin is a small thaumatin belonging to this subfamily, we performed fragmentbased molecular modelling [48,49]. A zeamatin sequence was used as the basis for the fragment of $A q G P$ and then this chimeric sequence was modeled. The fragment is near the N-terminal region of the protein in domain I and covers the beginning of domain III (Figure 4); this region has been predicted as a possible allergen epitope in other thaumatins, including Ban-TLP [43] and NP24-I [40]. The predicted three-dimensional structure, including the fragment, showed little modification in the RMSD $(0.224 \AA)$ in comparison with the zeamatin structure, indicating the absence of structural modifications. Although the fragment does not cover domain II, AqGP thaumatin does not necessarily belong to the small thaumatin subfamily. Given the similar anti-inflammatory properties of AqGP and osmotin [20,21], and the fact that the osmotin activity is related to domain II [20], it is possible that $A q G P$ also contains domain II, which would characterize it as a thaumatin.

\section{Materials and Methods}

\subsection{Plant Material}

The rhizome of G. paniculata was collected in the city of Cristalina, Goiás state, Brazil.

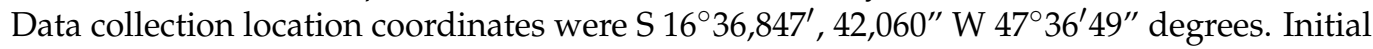
botanical identification was performed by Dr. Dalva Graciano Ribeiro, from the Department of Botany, University of Brasilia, Brasilia (UnB), Brazil. A voucher specimen used in the identification was deposited in the UnB herbarium (protocol: 151468). The access to botanical material was registered in the Management System of Genetic Patrimony and Associated Folk Knowledge-SISGEN, Brazil ( ${ }^{\circ}$. A84EB12).

\subsection{Plant Extract Preparation}

The rhizome was washed with tap water, and immediately pulverized in a knife mill. The raw material was then dried at $50{ }^{\circ} \mathrm{C}$ in a forced ventilation kiln, and afterwards stored at room temperature in a cool dry place. The resulting powder was macerated in water $1 / 10(w / v)$. The solution was maintained at $4{ }^{\circ} \mathrm{C}$ for $5 \mathrm{~h}$ and periodically stirred for $30 \mathrm{~min}$ intervals. The solution was then filtered through cheesecloth and centrifuged at $4{ }^{\circ} \mathrm{C}, 6000 \mathrm{~g}$ for $30 \mathrm{~min}$. The pellet was discarded, and the supernatant was subjected to filtration using a $45 \mu \mathrm{m}$ filter. The filtrate was lyophilized and stored at room temperature until further use $[50,51]$.

\subsection{Evaluation of Cell Viability}

\subsubsection{Hemolytic Activity Test}

Hemolytic activity was evaluated according to Aboudy and co-workers with some modifications [52]. Ten $\mu \mathrm{L}$ of $A q G P$ with the concentrations of $0.32,0.64,1.28,2.56,5.12$, and $10.24 \mathrm{mg} / \mu \mathrm{L}^{-1}$ was diluted in phosphate buffered saline (PBS), $\mathrm{pH} 7.4$ was added to $190 \mu \mathrm{L}$ 
of goat heparinized blood, washed and diluted to $8 \%$ (resulting in final concentrations of $0.32,0.64,1.28,2.56,5.12$, and $10.24 \mathrm{mg} / \mu \mathrm{L}$ ). After this procedure, the mixtures were incubated at $37^{\circ} \mathrm{C}$ for $30 \mathrm{~min}$ under slow stirring. The material was centrifuged at $2000 \mathrm{~g}$ and incubated for $5 \mathrm{~min}$ at room temperature. The absorbance was monitored at $540 \mathrm{~nm}$. The supernatant was then analyzed using a microplate spectrophotometer (Powerwave HT, Santa Ana, CA, USA). PBS and Triton ${ }^{\mathrm{TM}}$ X-100 (Sigma-Aldrich, St. Louis, MO, USA) $0.2 \%$ were used as negative and positive control, respectively. Three replicates were performed, and the procedure was repeated three times.

\subsubsection{MTT Assay}

Murine NIH/3T3-fibroblast and MCF-7 human breast tumor cell lines were cultured in Dulbecco's modified Eagle medium (DMEM; Gibco, Waltham, MA, USA) supplemented with $10 \%$ fetal bovine serum (Gibco), penicillin (100 U/mL) (Sigma-Aldrich), and streptomycin $(100 \mathrm{mM} / \mathrm{mL})$ (Sigma-Aldrich) and maintained at $37^{\circ} \mathrm{C}$ in an atmosphere of $5 \%$ $\mathrm{CO}_{2}$. Cell cultures were maintained as described previously by Silva and co-workers [18] Cells were removed ( $80 \%$ confluence) with the aid of a plastic carrier (TPP, Trasadingen, Schaffhausen, Switzerland). The cell concentration was adjusted to $1 \times 10^{5}$ cells $/ \mathrm{mL}$. Cells were incubated in a 96-well (TPP) plate for $24 \mathrm{~h}$, along with AqGP at various concentrations $(0.32,0.64,1.28,2.56,5.12$, and $10.24 \mathrm{mg} / \mu \mathrm{L})$. The plate was incubated at $37^{\circ} \mathrm{C}$, $5 \% \mathrm{CO}_{2}$. For the control treatment, the cells were incubated with PBS. After the incubation period, $150 \mu \mathrm{L}$ (3-(4,5-dimethylthiazol-2-yl)-2,5-diphenyltetrazolium bromide) (MTT; Sigma-Aldrich) solution ( $5 \mathrm{mg} / \mathrm{mL}$ ) diluted in $135 \mu \mathrm{L}$ of DMEM (Gibco) was added to each well of the plate and again incubated for $3 \mathrm{~h}$ at $37{ }^{\circ} \mathrm{C}$ and $5 \% \mathrm{CO}_{2}$ (in the dark). Subsequently, the microplate was centrifuged at $800 \mathrm{~g}$ for $5 \mathrm{~min}$. The supernatant was removed, and formazan crystals were dissolved in $100 \mu \mathrm{L}$ of DMSO (J.T. Baker, Center Valley, CA, USA) and stirred for $10 \mathrm{~min}$ at room temperature. The absorbance was monitored at 575 nm using a microplate reader (Bio-Tek, Winooski, VT, USA). Cell viability was expressed as a percentage compared to the untreated negative control cells and the positive control cells, which were treated with lysis solution (10 mM Tris-HCl, pH 7.4; 1 mM EDTA, 0.1\% Triton X-100 (J.T. Baker, Center Valley, CA, USA)).

\subsection{Animals}

Male and female Swiss mice weighing 18-22 g (6 weeks) were obtained by the Bioterium of Universidade Catolica Dom Bosco (UCDB). Protocol number: 006/11. The animals were kept under conditions of controlled temperature $\left(23-25^{\circ} \mathrm{C}\right)$ and light/dark cycle, with free access to food and water.

\subsection{Evaluation of Nociceptive Response}

\subsubsection{Formalin Testsed}

Nociceptive stimulation was performed by applying $20 \mu \mathrm{L}$ of formalin (2.5\%) (diluted in sterile saline) to the sub-plantar region of the right paw of mice $(n=5)$. The response to the stimulus was evaluated by observing the licking of the injured paw. Predetermined doses of $A q G P$ were applied subcutaneously to the back of the animal $15 \mathrm{~min}$ before the nociceptive stimulus. The same procedure was performed with acetylsalicylic acid (SigmaAldrich), a proven acting analgesic. The number of licks was observed in two stages, first in the period 0-5 min after stimulation (step 1), and later in the period 15 to $30 \mathrm{~min}$ after stimulation (step 2) [33,53].

\subsubsection{Acetic Acid-Induced Abdominal Contortions}

The mouse writhing test was performed based on the method of Koster et al. [54]. The mice were pre-treated with $0.9 \%$ saline, acetylsalicylic acid $(100 \mathrm{mg} / \mathrm{kg}), A q G P 1.0,5.0$, and $10 \mathrm{mg} / \mathrm{kg}$ (s.c). Acetic acid (0.8\%, $100 \mu \mathrm{L}$, i.p.) was given $15 \mathrm{~min}$ after treatment. Immediately after the injection of a nociceptive stimulus, the number of abdominal contortions, 
characterized by abdominal rotation and total stretching of the hind paws were counted for $30 \mathrm{~min}$.

\subsection{Anti-Inflammatory Assay: Neutrophil Migration}

The inflammatory process was performed as describe by Roriz and colleagues [55] and induced by application of $500 \mu \mathrm{L}$ thioglycolate (Merck, Kenilworth, NJ, USA) 4\% per animal $(n=5)$, in the intraperitoneal region. After $6 \mathrm{~h}$ of phlogiston stimulation, the animals were euthanized in a $\mathrm{CO}_{2}$ chamber. Subsequently, an incision was made to expose the animal's intraperitoneal region, which was washed with $3 \mathrm{~mL}$ of isotonic EDTA solution $(32 \%(w / v))$. An aliquot of $20 \mu \mathrm{L}$ of this washed material (exudate) was collected and mixed with $380 \mu \mathrm{L}$ of Turk blue to achieve the overall cell count using a Neubauer chamber. The cell exudates were precipitated by centrifugation at $2800 \times g$ for $2 \mathrm{~min}$ and used for smear preparation. After this process, the material was stained with Quick Kit Panoptic (Laborclin, Rio Preto, SP, Brazil) and used for differential counts. For the control, $500 \mu \mathrm{L}$ of $0.9 \%$ saline solution $(w / v)$ was administered intraperitoneally. After this procedure, the material was submitted to the procedures described above. To evaluate the effect of AqGP and its fractions on the migration process, predetermined doses of $100 \mu \mathrm{L}$ were applied subcutaneously to the back of the animal, $15 \mathrm{~min}$ before the inflammatory stimulus by thioglycolate (Merck). For quantitative analysis of the material, the same procedure was performed with anti-inflammatory Dexamethasone (Sigma-Aldrich) $(0.5 \mathrm{mg} / \mathrm{kg})$.

\subsection{Anti-Inflammatory Bioassay Guided Fractionation}

\subsubsection{Dialysis Fractionation}

The lyophilized plant extract was dissolved in $10 \mathrm{~mL}$ of distilled $\mathrm{H}_{2} \mathrm{O}$ and then fractionated by dialysis against distilled $\mathrm{H}_{2} \mathrm{O}$ using a membrane (Spectrum Laboratories Inc, Rancho Dominguez, CA, USA) of pore size of $3.5 \mathrm{kDa}$. Dialysis processes were maintained at $4{ }^{\circ} \mathrm{C}$ for $48 \mathrm{~h}$ under slow agitation and periodic changes of distilled $\mathrm{H}_{2} \mathrm{O}$, always in a proportion of $1 / 200 \mathrm{H}_{2} \mathrm{O}$. The two fractions obtained by this process (internal dialysate molecules $>3.5 \mathrm{kDa}$ and external dialysate molecules $<3.5 \mathrm{kDa}$ ) were lyophilized and then subjected to biological evaluation of anti-inflammatory action by neutrophil migration [56].

\subsubsection{Fractionation by Ammonium Sulfate Precipitation}

The internal dialyzed fraction, containing molecules larger than $3.5 \mathrm{kDa}$, was subjected to precipitation by ammonium sulfate (Sigma-Aldrich). This fraction was quantified by Bradford (Bio-Rad Laboratories, Hercules, CA, USA) [57] and diluted in water in a ratio of $1 \mathrm{mg} / \mathrm{mL}$. After this procedure, the material was precipitated by saturation in $0-30 \%$, $30-60 \%$, and $60-90 \%$ ammonium sulfate, according to the table available in [58]. At each stage of saturation, the material was maintained at $4{ }^{\circ} \mathrm{C}$ for $4 \mathrm{~h}$, and subsequently centrifuged at $7500 \mathrm{~g}$ for $15 \mathrm{~min}$. The precipitate was diluted in distilled $\mathrm{H}_{2} \mathrm{O}$ and dialyzed against a membrane of $3.5 \mathrm{kDa}$ pore size for desalination. The precipitated fractions and the non-precipitated fraction from $60-90 \%$ were subjected to biological evaluation of anti-inflammatory action by neutrophil migration.

\subsubsection{Fractionation by High Performance Liquid Chromatography}

The fraction saturated with 0-30\% ammonium sulfate was desalinized, lyophilized, and resuspended in $0.1 \%$ TFA (J.T. Baker, USA), and further purified using HPLC (Shimadzu, Japan) on a Vydac ${ }^{\mathrm{TM}}$ C4 semi-preparative column (Grace, Bannockburn, IL, USA), with a nonlinear acetonitrile (J.T. Baker, USA) gradient (5-95\%) at a flow rate of $2.5 \mathrm{~mL} / \mathrm{min}$. Sample elution was monitored at 216 and $280 \mathrm{~nm}$. The HPLC fraction obtained in the retention time of $29.9 \mathrm{~min}(500 \mu \mathrm{g})$ was applied onto a HPLC and eluted with a linear gradient (5-95\% acetonitrile), at a flow rate of $1 \mathrm{~mL} / \mathrm{min}$ using an analytical $\mathrm{C}_{4}$ column (Grace ${ }^{\circledR}$, Columbia, USA). All fractions were lyophilized and submitted to biological assay to evaluate the anti-inflammatory effects by neutrophil migration [56]. 


\subsection{Chemical Identification Methods \\ 3.8.1. SDS-PAGE Analysis}

The selected fractions from the purification steps ( $A q G P$, internal dialysate, $0-30 \%$ ammonium sulfate saturation, and the peak resulting from the chromatography step), containing $40 \mu \mathrm{g}$ each were resuspended in $15 \mu \mathrm{L}$ of $1 \times$ sample buffer and then boiled for $5 \mathrm{~min}$. Samples were then loaded in SDS-PAGE 12\% [59]. The proteins were separated by applying a voltage of $15 \mathrm{~mA}$ for the concentration gel and $25 \mathrm{~mA}$ for the separating gel. After the electrophoresis process the gel was stained with Coomassie brilliant blue (Thermo Scientific, Waltham, MA, USA) and silver (Sigma-Aldrich).

\subsubsection{Mass Spectrometry Analysis by MALDI-TOF}

The fractions were diluted in $10 \mu \mathrm{L}$ of Milli-Q $\mathrm{H}_{2} \mathrm{O}$ and an aliquot $(1 \mu \mathrm{L})$ was mixed with saturated solution of acid matrix $\alpha$-cyano-4-hydroxycinnamic acid (Bruker Daltonics, Bremen, Germany) in a 1:3 ratio (sample:matrix $v / v$ ). The mixture was applied onto a steel plate for MALDI-TOF and inserted into a UltraFlex III MALDI-TOF mass spectrometer (Bruker Daltonics) after crystallization at room temperature. Data were collected by FlexControl software version 3.0, and the mass spectra were acquired in linear and reflector modes, using external calibration. For the linear mode, the samples were analyzed utilizing a range between $m / z 4000-25,000$ and $m / z$ 20,000-140,000. The calibrants used were the Protein Calibration Standards I and II (Bruker Daltonics). For the reflector mode, the samples were analyzed in a range of $m / z$ 1000-4000. The calibrant used was Peptide Calibration Standard I (Bruker Daltonics). Intact protein fragmentation was accomplished directly in the in-source decay mode (ISD) with a 1,5-diaminonaphthalene (DAN) matrix (Sigma-Aldrich). This mode, comprising a range of $m / z$ 1000-6000, allowed for manual interpretation of the spectrum from the ions $\mathrm{c}$ series, which enabled the elucidation of a partial primary structure for the intact protein. The sequences obtained were submitted to a local sequence alignment search against the NCBI protein database using BLASTp [60].

\subsection{Fragment-Based Modeling}

The fragment retrieved from mass spectrometry analysis was submitted to a PSIBLAST [60] search against the protein data bank, through four iterations, when no new sequences were retrieved. The sequences were aligned with the fragment by means of ClustalW2 [61]. The molecular model was constructed according to fragment-based modelling $[48,49]$, with minor modifications. A chimeric sequence was constructed, introducing the G. paniculata fragment into the zeamatin sequence [39]. Modeller 9.17 [62] was used to construct 100 models, using the zeamatin structure (PDB ID: 1DU5) as the template. The models were constructed using the default methods of automodel and environ classes from MODELLER. The final models were selected according to the discrete optimized protein energy score (DOPE score). This score assesses the energy of the model and indicates the best probable structures. The best models were evaluated through PROSA II [63] and PROCHECK [64]. PROCHECK checks the stereochemical quality of a protein structure through the Ramachandran plot. Good quality models are expected to have more than $90 \%$ of amino acid residues in the most favored and additional allowed regions, while PROSA II indicates the fold quality. The root mean square deviation (RMSD) between the zeamatin structure and the chimeric structure was calculated by using a 3dSS server [65] by means of STAMP algorithm [66]. Structure visualization was done in PyMOL [67]

\subsection{Statistical Analysis}

Data are presented as the mean $\pm \mathrm{SD}$. Comparisons between two groups were made by an unpaired $t$ test. Comparisons between more than two groups were submitted to one-way analysis of variance (ANOVA) followed by Bonferroni correction. Values of $p<0.05$ were considered statistically significant. GraphPad Prism software v 6.0 (GraphPad Software, La Jolla, CA, USA) was used for all statistical analyses. 


\section{Conclusions}

In conclusion, we demonstrated the anti-inflammatory and analgesic properties of G. paniculata aqueous extracts. A thaumatin-like protein isolated from these aqueous extracts appears to act as the active principle of such activities. This fact is reinforced by the similarity to osmotin, another thaumatin-like protein, which presents analgesic effects. These data suggest that the isolated protein either alone or together with other molecules is responsible for the anti-inflammatory activity of the G. paniculata rhizome used in Brazilian folk medicine. Despite the fact that thaumatins may present an allergenic epitope, our data indicated that the thaumatin-like protein from G. paniculata is safe to be used as a drug. However, further studies are needed for a better characterization of this compound, regarding its primary structure and characterization of its epitopes and the determination of the small active fragments. Nevertheless, the identification of anti-inflammatory and analgesic properties from a thamatin-like protein could expand the repertory of biological activities from this protein family. Moreover, the identification of such a potential drug from G. paniculata, reinforces the folk medicine as a resource for bioactive molecules.

Author Contributions: Conceptualization, T.L.R., R.d.A.C. and S.E.M.; Formal analysis, B.A.S., O.N.S., J.O.F., O.L.F. and S.E.M.; Funding acquisition, M.F.G.-d.-S.; Investigation, B.A.S., O.N.S., L.P.S., D.F.B., J.O.F. and C.d.l.F.N.; Methodology, B.A.S., W.F.P., L.P.S., A.P.F.L. and D.F.B.; Project administration, S.E.M.; Supervision, T.L.R., M.F.G.-d.-S. and S.E.M.; Validation, R.d.A.C.; Writing —original draft, B.A.S., O.N.S., L.P.S., D.F.B. and C.d.I.F.N.; Writing-review \& editing, W.F.P. All authors have read and agreed to the published version of the manuscript.

Funding: S.A.B acknowledges a scholarship from the Coordenação de Aperfeiçoamento de Pessoal de Nível Superior (CAPES); O.N.S. holds a postdoctoral scholarship from the CAPES, Fundação de Amparo a Pesquisa do Estado de Goiás (88887.370078/2019-00), Conselho Nacional de Desenvolvimento Científico e Tecnológico (CNPq) and Fundação de Apoio ao Desenvolvimento do Ensino, Ciência e Tecnologia do Estado de Mato Grosso do Sul (FUNDECT)[300583/2016-8]. C.F.N. holds a Presidential Professorship at the University of Pennsylvania, is a recipient of the Langer Prize by the AIChE Foundation and acknowledges funding from the Institute for Diabetes, Obesity, and Metabolism, the Penn Mental Health AIDS Research Center of the University of Pennsylvania, the National Institute of General Medical Sciences of the National Institutes of Health under award number R35GM138201, and the Defense Threat Reduction Agency (DTRA; HDTRA11810041 and HDTRA1-21-1-0014).

Institutional Review Board Statement: The animals were handled according to procedures for the scientific use of animals established by law $\mathrm{N}^{\circ} 11.794$ on the 8th of October 2008 and in accordance with the Ethical Principles for the use of Laboratory Animals recommended by CONCEA (National Council for Control of Animal Experimentation-Brazil) and approved by the Ethics Committee on the use of animals (CEUA) of the UCDB (Approval number 006/11).

Data Availability Statement: The data presented in this study are available on request from the corresponding author.

Acknowledgments: We thank Dalva Graciano Ribeiro, from the Department of Botany, University of Brasilia (UnB) for G. paniculata botanical identification.

Conflicts of Interest: The authors whose names are listed immediately below certify that they have NO affiliations with or involvement in any organization or entity with any financial interest (such as honoraria; educational grants; participation in speakers' bureaus; membership, employment, consultancies, stock ownership, or other equity interest; and expert testimony or patent-licensing arrangements), or non-financial interest (such as personal or professional relationships, affiliations, knowledge or beliefs) in the subject matter or materials discussed in this manuscript.

Sample Availability: Samples of the G. paniculata rhizome are available from the authors. 


\section{References}

1. Medzhitov, R. Origin and physiological roles of inflammation. Nature 2008, 454, 428-435. [CrossRef] [PubMed]

2. Katz, J.; Rosenbloom, B.N.; Fashler, S. Chronic Pain, Psychopathology, and DSM-5 Somatic Symptom Disorder. Can. J. Psychiatry. 2015, 60, 160-167. [CrossRef]

3. Jaillon, S.; Galdiero, M.R.; Del Prete, D.; Cassatella, M.A.; Garlanda, C.; Mantovani, A. Neutrophils in innate and adaptive immunity. Semin. Immunopathol. 2013, 35, 377-394. [CrossRef] [PubMed]

4. Mantovani, A.; Cassatella, M.A.; Costantini, C.; Jaillon, S. Neutrophils in the activation and regulation of innate and adaptive immunity. Nat. Rev. Immunol. 2011, 11, 519-531. [CrossRef]

5. Brown, K.A.; Brain, S.D.; Pearson, J.D.; Edgeworth, J.D.; Lewis, S.M.; Treacher, D.F. Neutrophils in development of multiple organ failure in sepsis. Lancet 2006, 368, 157-169. [CrossRef]

6. Coutinho, A.E.; Chapman, K.E. The anti-inflammatory and immunosuppressive effects of glucocorticoids, recent developments and mechanistic insights. Mol. Cell. Endocrinol. 2011, 335, 2-13. [CrossRef] [PubMed]

7. Batlouni, M. Nonsteroidal anti-inflammatory drugs: Cardiovascular, cerebrovascular and renal effects. Arq. Bras. Cardiol. 2010, 94, 556-563. [CrossRef] [PubMed]

8. Cole, G.M.; Frautschy, S.A. Mechanisms of action of non-steroidal anti-inflammatory drugs for the prevention of Alzheimer's disease. CNS Neurol. Disord. Drug Targets 2010, 9, 140-148. [CrossRef]

9. Odabasoglu, F.; Cakir, A.; Suleyman, H.; Aslan, A.; Bayir, Y.; Halici, M.; Kazaz, C. Gastroprotective and antioxidant effects of usnic acid on indomethacin-induced gastric ulcer in rats. J. Ethnopharmacol. 2006, 103, 59-65. [CrossRef]

10. Adebayo, S.A.; Dzoyem, J.P.; Shai, L.J.; Eloff, J.N. The anti-inflammatory and antioxidant activity of 25 plant species used traditionally to treat pain in southern African. BMC Complement. Altern. Med. 2015, 15, 159. [CrossRef]

11. Pinto, M.F.S.; Silva, O.N.; Viana, J.C.; Porto, W.F.; Migliolo, L.; Da Cunha, N.B.; Gomes, N.; Fensterseifer, I.C.M.; Colgrave, M.L.; Craik, D.J.; et al. Characterization of a Bioactive Acyclotide from Palicourea rigida. J. Nat. Prod. 2016. [CrossRef] [PubMed]

12. Nürnberger, T.; Brunner, F. Innate immunity in plants and animals: Emerging parallels between the recognition of general elicitors and pathogen-associated molecular patterns. Curr. Opin. Plant Biol. 2002, 5, 318-324. [CrossRef]

13. Katiyar, C.; Gupta, A.; Kanjilal, S.; Katiyar, S. Drug discovery from plant sources: An integrated approach. Ayu 2012, 33, 10-19. [CrossRef] [PubMed]

14. Pinto, M.F.S.; Almeida, R.G.; Porto, W.F.; Fensterseifer, I.C.M.; Lima, L.A.; Dias, S.C.; Franco, O.L. Cyclotides: From Gene Structure to Promiscuous Multifunctionality. J. Evid. Based. Complement. Altern. Med. 2012, 17, 40-53. [CrossRef]

15. Silva, O.N.; Porto, W.F.; Migliolo, L.; Mandal, S.M.; Gomes, D.G.; Holanda, H.H.S.; Silva, R.S.P.; Dias, S.S.C.; Costa, M.P.; Costa, C.R.; et al. Cn-AMP1: A new promiscuous peptide with potential for microbial infections treatment. Biopolymers 2012, 98, 322-331. [CrossRef] [PubMed]

16. de la Fuente-Núez, C.; Mansour, S.; Wang, Z.; Jiang, L.; Breidenstein, E.; Elliott, M.; Reffuveille, F.; Speert, D.; Reckseidler-Zenteno, S.; Shen, Y.; et al. Anti-Biofilm and Immunomodulatory Activities of Peptides That Inhibit Biofilms Formed by Pathogens Isolated from Cystic Fibrosis Patients. Antibiotics 2014, 3, 509-526. [CrossRef]

17. De la Fuente-Núñez, C.; Reffuveille, F.; Fernández, L.; Hancock, R.E.W. Bacterial biofilm development as a multicellular adaptation: Antibiotic resistance and new therapeutic strategies. Curr. Opin. Microbiol. 2013, 16, 580-589. [CrossRef]

18. Silva, O.N.; Fensterseifer, I.C.M.; Rodrigues, E.A.; Holanda, H.H.S.; Novaes, N.R.F.; Cunha, J.P.A.; Rezende, T.M.B.; Magalhães, K.G.; Moreno, S.E.; Jerônimo, M.S.; et al. Clavanin A Improves Outcome of Complications from Different Bacterial Infections. Antimicrob. Agents Chemother. 2014. [CrossRef]

19. Mansour, S.C.; de la Fuente-Núñez, C.; Hancock, R.E.W. Peptide IDR-1018: Modulating the immune system and targeting bacterial biofilms to treat antibiotic-resistant bacterial infections. J. Pept. Sci. 2015, 21, 323-329. [CrossRef] [PubMed]

20. Miele, M.; Costantini, S.; Colonna, G. Structural and functional similarities between osmotin from Nicotiana tabacum seeds and human adiponectin. PLoS ONE 2011, 6, e16690. [CrossRef]

21. Arsenescu, V.; Narasimhan, M.L.; Halide, T.; Bressan, R.A.; Barisione, C.; Cohen, D.A.; de Villiers, W.J.S.; Arsenescu, R. Adiponectin and Plant-Derived Mammalian Adiponectin Homolog Exert a Protective Effect in Murine Colitis. Dig. Dis. Sci. 2011, 56, 2818-2832. [CrossRef]

22. Fangkrathok, N.; Junlatat, J.; Sripanidkulchai, B. In vivo and in vitro anti-inflammatory activity of Lentinus polychrous extract. J. Ethnopharmacol. 2013, 147, 631-637. [CrossRef] [PubMed]

23. Buapool, D.; Mongkol, N.; Chantimal, J.; Roytrakul, S.; Srisook, E.; Srisook, K. Molecular mechanism of anti-inflammatory activity of Pluchea indica leaves in macrophages RAW 264.7 and its action in animal models ofinflammation. J. Ethnopharmacol. 2013, 146, 495-504. [CrossRef] [PubMed]

24. Hanáková, Z.; Hošek, J.; Kutil, Z.; Temml, V.; Landa, P.; Vaněk, T.; Schuster, D.; Dall'Acqua, S.; Cvačka, J.; Polanský, O.; et al. Anti-inflammatory Activity of Natural Geranylated Flavonoids: Cyclooxygenase and Lipoxygenase Inhibitory Properties and Proteomic Analysis. J. Nat. Prod. 2017, 80, 999-1006. [CrossRef] [PubMed]

25. Moreira, D.D.L.; Teixeira, S.S.; Monteiro, M.H.D.; De-Oliveira, A.C.A.X.; Paumgartten, F.J.R. Traditional use and safety of herbal medicines. Rev. Bras. Farmacogn. 2014, 24, 248-257. [CrossRef]

26. Calixto, J.B. Efficacy, safety, quality control, marketing and regulatory guidelines for herbal medicines (phytotherapeutic agents). Brazilian J. Med. Biol. Res. 2000, 33, 179-189. [CrossRef] [PubMed] 
27. de Abreu Matos, F.J. Farmaácias Vivas: Sistema de Utilizaçaão de Plantas Medicinais Projetado Para Pequenas Comunidades, 4th ed.; UFC: Fortaleza-CE, Brazil, 2002; ISBN 8572820086.

28. Smith, U. Dietary fibre, diabetes and obesity. Int. J. Obes. 1987, 11 (Suppl. 1), 27-31. [CrossRef]

29. Chongtham, N.; Bisht, M.S.; Haorongbam, S. Nutritional Properties of Bamboo Shoots: Potential and Prospects for Utilization as a Health Food. Compr. Rev. Food Sci. Food Saf. 2011, 10, 153-168. [CrossRef]

30. Lu, B.; Wu, X.; Tie, X.; Zhang, Y.; Zhang, Y. Toxicology and safety of anti-oxidant of bamboo leaves. Part 1: Acute and subchronic toxicity studies on anti-oxidant of bamboo leaves. Food Chem. Toxicol. 2005, 43, 783-792. [CrossRef]

31. Lehto, M.; Airaksinen, L.; Puustinen, A.; Tillander, S.; Hannula, S.; Nyman, T.; Toskala, E.; Alenius, H.; Lauerma, A. Thaumatinlike protein and baker's respiratory allergy. Ann. Allergy Asthma Immunol. 2010, 104, 139-146. [CrossRef]

32. Tschannen, M.P.; Glück, U.; Bircher, A.J.; Heijnen, I.; Pletscher, C. Thaumatin and gum arabic allergy in chewing gum factory workers. Am. J. Ind. Med. 2017, 60, 664-669. [CrossRef]

33. Tjølsen, A.; Berge, O.G.; Hunskaar, S.; Rosland, J.H.; Hole, K. The formalin test: An evaluation of the method. Pain 1992, 51, 5-17. [CrossRef]

34. de Oliveira Júnior, J.O.; Portella Junior, C.S.A.; Cohen, C.P. Inflammatory mediators of neuropathic pain. Rev. Dor 2016, 17, 35-42. [CrossRef]

35. Serbina, N.V.; Jia, T.; Hohl, T.M.; Pamer, E.G. Monocyte-mediated defense against microbial pathogens. Annu. Rev. Immunol. 2008, 26, 421-452. [CrossRef]

36. Qureshi, R.; Jakschik, B.A. The role of mast cells in thioglycollate-induced inflammation. J. Immunol. 1988, 141, $2090-2096$.

37. Ness, T.J. Models of Visceral Nociception. ILAR J. 1999, 40, 119-128. [CrossRef]

38. Ferreira, S. Peripheral analgesia: Mechanism of the analgesic action of aspirin-like drugs and opiate-antagonists. Br. J. Clin. Pharmacol. 1980, 10, 237S-245S. [CrossRef]

39. Batalia, M.A.; Monzingo, A.F.; Ernst, S.; Roberts, W.; Robertus, J.D. The crystal structure of the antifungal protein zeamatin, a member of the thaumatin-like, PR-5 protein family. Nat. Struct. Biol. 1996, 3, 19-23. [CrossRef]

40. Ghosh, R.; Chakrabarti, C. Crystal structure analysis of NP24-I: A thaumatin-like protein. Planta 2008, 228, 883-890. [CrossRef]

41. Ramos, M.V.; de Oliveira, R.S.B.; Pereira, H.M.; Moreno, F.B.M.B.; Lobo, M.D.P.; Rebelo, L.M.; Brandão-Neto, J.; de Sousa, J.S.; Monteiro-Moreira, A.C.O.; Freitas, C.D.T.; et al. Crystal structure of an antifungal osmotin-like protein from Calotropis procera and its effects on Fusarium solani spores, as revealed by atomic force microscopy: Insights into the mechanism of action. Phytochemistry 2015, 119, 5-18. [CrossRef]

42. Marangon, M.; Van Sluyter, S.C.; Waters, E.J.; Menz, R.I. Structure of Haze Forming Proteins in White Wines: Vitis vinifera Thaumatin-Like Proteins. PLoS ONE 2014, 9, e113757. [CrossRef] [PubMed]

43. Leone, P.; Menu-Bouaouiche, L.; Peumans, W.J.; Payan, F.; Barre, A.; Roussel, A.; Van Damme, E.J.M.; Rougé, P. Resolution of the structure of the allergenic and antifungal banana fruit thaumatin-like protein at 1.7-Å. Biochimie 2006, 88, 45-52. [CrossRef] [PubMed]

44. Min, K.; Ha, S.C.; Hasegawa, P.M.; Bressan, R.A.; Yun, D.-J.; Kim, K.K. Crystal structure of osmotin, a plant antifungal protein. Proteins Struct. Funct. Bioinform. 2003, 54, 170-173. [CrossRef]

45. Ko, T.P.; Day, J.; Greenwood, A.; McPherson, A. Structures of three crystal forms of the sweet protein thaumatin. Acta Crystallogr. Sect. D Biol. Crystallogr. 1994, 50, 813-825. [CrossRef] [PubMed]

46. Vandermarliere, E.; Lammens, W.; Schoepe, J.; Rombouts, S.; Fierens, E.; Gebruers, K.; Volckaert, G.; Rabijns, A.; Delcour, J.A.; Strelkov, S.V.; et al. Crystal structure of the noncompetitive xylanase inhibitor TLXI, member of the small thaumatin-like protein family. Proteins Struct. Funct. Bioinform. 2010, 78, 2391-2394. [CrossRef]

47. Shah, S.A.; Lee, H.Y.; Bressan, R.A.; Yun, D.J.; Kim, M.O. Novel osmotin attenuates glutamate-induced synaptic dysfunction and neurodegeneration via the JNK/PI3K/Akt pathway in postnatal rat brain. Cell Death Dis. 2014, 5. [CrossRef]

48. Pang, C.; Cao, T.; Li, J.; Jia, M.; Zhang, S.; Ren, S.; An, H.; Zhan, Y. Combining fragment homology modeling with molecular dynamics aims at prediction of Ca2+ binding sites in CaBPs. J. Comput. Aided. Mol. Des. 2013, 27, 697-705. [CrossRef] [PubMed]

49. Kelm, S.; Vangone, A.; Choi, Y.; Ebejer, J.-P.; Shi, J.; Deane, C.M. Fragment-based modeling of membrane protein loops: Successes, failures, and prospects for the future. Proteins Struct. Funct. Bioinform. 2014, 82, 175-186. [CrossRef]

50. Fernando, I.P.S.; Sanjeewa, K.K.A.; Lee, H.G.; Kim, H.-S.; Vaas, A.P.J.P.; De Silva, H.I.C.; Nanayakkara, C.M.; Abeytunga, D.T.U.; Lee, D.-S.; Lee, J.-S.; et al. Fucoidan Purified from Sargassum polycystum Induces Apoptosis through Mitochondria-Mediated Pathway in HL-60 and MCF-7 Cells. Mar. Drugs 2020, 18, 196. [CrossRef]

51. Kamada, T.; Kang, M.-C.; Phan, C.-S.; Zanil, I.; Jeon, Y.-J.; Vairappan, C. Bioactive Cembranoids from the Soft Coral Genus Sinularia sp. in Borneo. Mar. Drugs 2018, 16, 99. [CrossRef]

52. Aboudy, Y.; Mendelson, E.; Shalit, I.; Bessalle, R.; Fridkin, M. Activity of two synthetic amphiphilic peptides and magainin-2 against herpes simplex virus types 1 and 2. Int. J. Pept. Protein Res. 1994, 43, 573-582. [CrossRef] [PubMed]

53. Hunskaar, S.; Hole, K. The formalin test in mice: Dissociation between inflammatory and non-inflammatory pain. Pain 1987, 30 , 103-114. [CrossRef]

54. Koster, R.; Anderson, M.; De-Beer, E. Acetic acid for analgesic screening. Fed. Proc. 1959, 18, $412-418$.

55. Roriz, B.C.; Buccini, D.F.; dos Santos, B.F.; Silva, S.R.D.S.; Domingues, N.L.D.C.; Moreno, S.E. Synthesis and biological activities of a nitro-shiff base compound as a potential anti-inflammatory agent. Eur. J. Pharm. Sci. 2020, 148, 105300. [CrossRef] 
56. Coldebella, P.F.; Gomes, S.D.; Evarini, J.A.; Cereda, M.P.; Coelho, S.R.M.; Coldebella, A. Evaluation of protein extraction methods to obtain protein concentrate from cassava leaf. Eng. Agric. 2013, 33, 1223-1233. [CrossRef]

57. Bradford, M.M. A rapid and sensitive method for the quantitation of microgram quantities of protein utilizing the principle of protein-dye binding. Anal. Biochem. 1976, 72, 248-254. [CrossRef]

58. EnCor Biotechnology Inc. Ammonium Sulfate Calculator. Available online: https://www.encorbio.com/protocols/AM-SO4.htm (accessed on 16 April 2018).

59. Laemmli, U.K. Cleavage of Structural Proteins during the Assembly of the Head of Bacteriophage T4. Nature 1970, 227, 680-685. [CrossRef]

60. Altschul, S.F.; Madden, T.L.; Schäffer, A.A.; Zhang, J.; Zhang, Z.; Miller, W.; Lipman, D.J. Gapped BLAST and PSI-BLAST: A new generation of protein database search programs. Nucleic Acids Res. 1997, 25, 3389-3402. [CrossRef] [PubMed]

61. Thompson, J.D.; Higgins, D.G.; Gibson, T.J. CLUSTAL W: Improving the sensitivity of progressive multiple sequence alignment through sequence weighting, position-specific gap penalties and weight matrix choice. Nucleic Acids Res. 1994, 22, 4673-4680. [CrossRef]

62. Webb, B.; Sali, A. Comparative Protein Structure Modeling Using MODELLER. In Current Protocols in Protein Science; John Wiley \& Sons, Inc.: Hoboken, NJ, USA, 2016; Volume 86, pp. 2.9.1-2.9.37.

63. Wiederstein, M.; Sippl, M.J. ProSA-web: Interactive web service for the recognition of errors in three-dimensional structures of proteins. Nucleic Acids Res. 2007, 35, W407-W410. [CrossRef]

64. Laskowski, R.A.; MacArthur, M.W.; Moss, D.S.; Thornton, J.M. PROCHECK: A program to check the stereochemical quality of protein structures. J. Appl. Crystallogr. 1993, 26, 283-291. [CrossRef]

65. Sumathi, K.; Ananthalakshmi, P.; Roshan, M.N.A.M.; Sekar, K. 3dSS: 3D structural superposition. Nucleic Acids Res. 2006, 34, W128-W132. [CrossRef] [PubMed]

66. Russell, R.B.; Barton, G.J. Multiple protein sequence alignment from tertiary structure comparison: Assignment of global and residue confidence levels. Proteins Struct. Funct. Genet. 1992, 14, 309-323. [CrossRef] [PubMed]

67. DeLano, W.L. The PyMOL Molecular Graphics System. Schrödinger LLC wwwpymolorg 2002. Version 1. Available online: https://pymol.org/2/ (accessed on 10 September 2018). 